DOI: $10.20472 / \mathrm{TE} .2016 .4 .2 .005$

\title{
RECULTURING: THE KEY TO SUSTAINAILITY OF PRIVATE UNIVERSITIES
}

\section{SING ONG YU}

\begin{abstract}
:
This article explores the key issues and challenges facing private university leaders today. Universities are reculturing their operational processes, academic content and interactions with stakeholders. Much challenges centred around the need for university leaders to reculture the institutions and the redesigning of the teaching profession. It recommends a framework for university leaders to deal with the challenges they face. Only through reculturing, private universities are able to maintain sustainability of its workforce and student population. The article has both theoretical and practical significance for private university leaders to follow.It presents a detailed theoretical framework for private universities as learning institution. The practical contribution of this paper emphasises the necessary actions university leaders must take to ensure a sustainable institution.
\end{abstract}

\section{Keywords:}

university leadership, reculturing, improvement

\section{Authors:}

SING ONG YU, Southern UNiversity College, Malaysia, Email: ysong@sc.edu.my

\section{Citation:}

SING ONG YU (2016). RECULTURING: THE KEY TO SUSTAINAILITY OF PRIVATE UNIVERSITIES.

International Journal of Teaching and Education, Vol. IV(2), pp. 88-105., 10.20472/TE.2016.4.2.005 


\section{INTRODUCTION}

This paper examines the process of reorientating as a key element towards university sustainability. It commences with a review of literature relating to the reorientationg of educational institutions and look at the challenges of developing a professional learning community (PLC). The second section proposes a framework of sustainability which considers environmental, social and economic factors. The final section of the paper provides some implications of this study for the private higher education sector.

Universities are finding it a challenge to attract and retain competent and qualified staff and faculty in the face of competition from other universities. Workforce sustainability is about attracting and retaining the right people with the right skills and competencies, to meet the current and future needs of the universities. It involves a high level of engagement and motivation of employees, so that they remain committed to their universities. The paper discusses how reorientating universities could lead to an environment which enhances human capital. The strategies could include: a) attracting and retaining the right people; b) accessing and growing their human capital; c) building, maintaining and engaging a high performing workforce; and d) maintaining a work-life balance for the staff and faculty.

\section{Attracting and retaining}

To attract and retain the right people, universities need to offer its employees workplace options which are flexible enough to meet their needs and changing circumstances. This includes promoting and encouraging diversity in views and opinions without fear of reprisals from university leaders.

This paper proposes a framework for university sustainability to include the following elements (Fig 1):

- Diversity

- Democracy

- Equity

- Quality

Diversity recognises that there are cultural, ethnic and religious groups differences. University leaders have to understand and accept that within the broader community, there are diverse viewpoints, beliefs and values. The extent to which democracy is exercised in a university reflects how much participation and representation of the relevant stakeholders is allowed by senior management of the university. The process of decision-making has to be made known and understood by the staff and other stakeholders. 
The pressure is on for the university's human resource manager to meet talent needs, manages organizational transformations and identifies talent gaps. An effective workforce with diverse skills and capabilities will support the university's goals to capitalize on its strengths and exploit opportunities regarding social and economic sustainability.

Very often, university administrators do not wish to acknowledge the importance of the key drivers of employee attraction and employee retention. Those drivers which relate to "curriculum" and "work environment" determine the extent of "Quality" improvements in the university. Those which relate to "fair compensation", "career advancement" and "learning and development" ensure there are "Equity" and opportunities in the organisation. Table 1 lists the key attraction and retention drivers.

"Democracy" gives rise to certain "decision-making" or "participation in decision making" within the university environment. Depending on the perception of employees on the importance of each driver, the inability to fulfil these drivers may prompt employees to seek opportunities elsewhere. Employee participation could be in the form of delegation of authority by the supervisor, psychological empowerment and power-sharing.

The concept of Partnership at Work is gaining popularity in many organisations. It calls for consultative arrangements among the various participants of the organisation and encapsulates features such as joint commitment of the parties to ensure success of the organisation, building trust by recognising legitimate roles and interests and addressing the quality of working life 


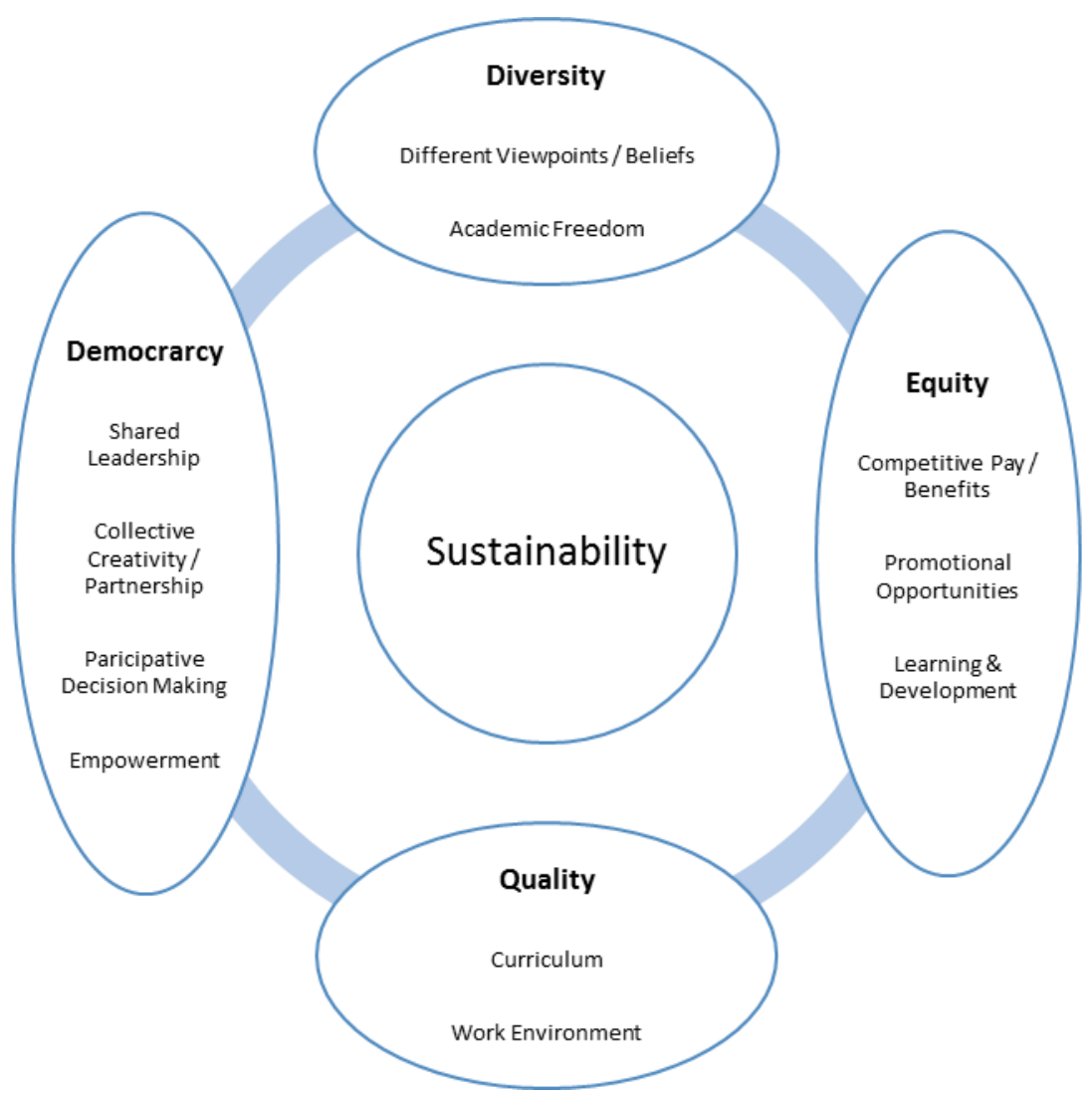

Fig 1: Proposed framework for university's sustainability

\begin{tabular}{|l|l|}
\hline Attraction Drivers & Retention Drivers \\
\hline Competitive salary & Competitive compensation \\
\hline Career advancement & $\begin{array}{l}\text { Opportunities to learn and develop } \\
\text { new skills and knowledge }\end{array}$ \\
\hline Competitive benefits & $\begin{array}{l}\text { Satisfaction with organisation's } \\
\text { decision }\end{array}$ \\
\hline $\begin{array}{l}\text { Salary increment due to } \\
\text { performance }\end{array}$ & Employee well-being \\
\hline $\begin{array}{l}\text { Learning \& Development } \\
\text { opportunities }\end{array}$ & $\begin{array}{l}\text { Decision-making authority } \\
\text { participation in decision making }\end{array}$ \\
\hline Profile of co-workers & Good colleagues \\
\hline $\begin{array}{l}\text { Reputation of university as a good } \\
\text { employer }\end{array}$ & $\begin{array}{l}\text { Reputation of university as caring } \\
\text { employer }\end{array}$ \\
\hline
\end{tabular}

Table 1: Key attraction and retention drivers in universities

Assessing and growing human capital

Assessing and growing human capital involve investing in talent development and offering opportunities for career progression. As with any comparable investment, the objective is to maximize value while managing risk. It requires careful planning that is 
in line with the university's vision. It also involves providing financial and non-financial support for those pursuing tertiary education or professional qualifications. University leaders need to adopt a management style in accordance to the way the university sees its mission. To create a workforce that shares this vision, university leaders have to gel the team to convey a clear and consistent portrayal of the vision by their words and actions. Huffman \& Jacobson (2003) asserted that principals' leadership practices are the best predictor for teachers' participation in change efforts.

\section{Building a high performance workforce}

Building and engaging a high performing workforce are critical to a university's competitiveness. University leaders have to understand that a high performance workforce will directly impact the performance of the university. It has to develop and implement a workforce plan which identifies skills and technical expertise needed and actions to meet those skills gaps. Other initiatives may include fostering innovation and creativity, leadership development and succession planning.

\section{Maintaining work-life balance}

The university has to adopt a strategy of building a highly-skilled, flexible and highperforming workforce. It can accomplish this by implementing comprehensive benefits and work-life programs. Employees expect employers to recognize that in addition to having a job, they also have a private life. A work-life balance policy reduces the stress employees experience. It enables them to feel that they are paying attention to all important aspects of their lives. Designing an effective work-life balance program will offer the university a competitive advantage in recruiting and retaining staff, increased productivity and increased customer service.

\section{IMPLICATIONS}

This study has much practical implications. It recognizes that private university leaders often operate under circumstances that are far from optimal. Very often, they may not understand the multiple complexities and challenges affecting their universities. This paper proposes a detailed framework focusing on the various elements and components of maintaining sustainability. At the heart of this is the reorientating of the universities. The findings will add significant new scholarly understanding of and insights into the complex environment of private universities and suggests ways in which implementation can be more structured.

\section{LITERATURE REVIEW}

The university's culture can either enhances or impedes professional learning. It enhances professional learning when employees believe professional development is important and that this belief and practice pervades throughout the whole organisation. 
Conversely, negative culture impairs staff development. The culture reflects a shared sense of purpose and values, a commitment to the learning of all students and opportunities for staff reflection and staff inquiry ((Stein, 1998; Lambert, 1998; Fullan, 2001; DuFour \& Eaker, 1998; Hord, 1998). Fullan, 1993 reiterated that change will require a radical reculturing of the school and the redesigning of the teaching profession. Studies have shown that a collaborative culture and teacher participation in decision making accompanied by transformational leadership are conditions that enhance professional learning and educational change in schools (Sleegers, Geijsel \& Van den Berg 2002, Geijsel, Sleegers, Stoel \& Kruger, 2007).

A study by $\mathrm{Yu}$ (2012) found that there are four issues and challenges facing university leaders today. These are: (1) ensuring academic freedom; (2) maintaining staff motivation; (3) maintaining academic quality and (4) providing effective leadership. Private university leaders may focus on competing paradigms such as "student as scholars" versus "students as consumers". Snyder et.al. (2007) and Giroux (2005) noted the interactive forces of mass education and of sound pedagogical principles in university education. The competitive pressure to recruit more students may prompt universities to lower the entry requirements of students, which in turn has negative implications on teachers' motivation.

University leaders have different views on delivering education based on sound principles of pedagogy and the need to create efficiencies of mass education (Coaldrake \& Stedman, 1999; Meek \& Wood,1997; Pratt \& Poole, 1999; Ramsden, 1998). Universities have opted for either larger classes or reduced contact time, or a combination of both due to resource reduction (Longden, 2006).

In today's competitive environment, leaders need to have the courage to take action when the future remains unclear (Barnett 2004) and Hanna (2003). In the process of developing the university as a learning organisation, the leader has to establish new relationships with all the stakeholders concerned. This paper examines the notion of leadership as being enabling and capacity building. It discusses through a process of reorientating the university as learning organisations, new capacities are being developed (Lingard, Hayes, Mills \& Christies, 2003; Hargreaves, 2003).

Reorientating is a process of organizational change. Fullan (1993) stated that when reculturing occurs, restructuring follows. Restructuring is not the same as reculturing as restructuring alters the structure of the organization and is often non-lasting. Reculturing results in longer lasting reforms (Boyd, 1992). It alters group dynamics and the ability of employees to self-access and reassess the environment. Staff have to understand the connections between their ideas about existing conditions and the strategies to reform them. It requires a link of culture to structure (Doyle 1998).

For reorientating to be successful, administrators need to facilitate change in others (Fawcett et al., 2001). That involves engaging staff in discussions that are driven by 
inquiry and self-reflection. Hargreaves (1994) found that creating structures for collaborations without creating relationships is unproductive. Administrators need to encourage teachers to raise issue and critique unpopular practices and ideologies within the university. Teachers have to experience shared leadership (Huffman \& Hipp, 2003) and commitment to the mission and goals of the school (Lee, Smith \& Croninger, 1995). There is also a need to have clarity of purpose (DuFour, DuFour, Eaker, \& Karhanek, 2004) and commitment to student learning (McLaughlin, 1993; Leithwood, Leonard, and Sharatt, 1998).

Spillane (2006) adopted a cognitive perspective when offering the distributed leadership framework as a diagnostic and design tool to help practitioners explore how the practice of leadership is "stretched over" multiple leaders, followers and situation. He suggested that leadership practice is constructed in the interactions between leaders, followers and their situations. Spillane highlights who takes responsibility for a task (he who leads is dictated by the task and not by his hierarchical position) and how the task is accomplished through interactions of multiple leaders and followers. Heck and Hallinger (1999) examined how leaders and others in the organization create shared understanding about their role and participation in school.

Ensuring academic freedom is critical to the reorientating efforts of a university. Barnett (1990) argued that academic freedom should be expanded from its narrow definition of staff immunity from censorship towards a universal mandate to present and to criticize ideas. Fessel (2006) urged universities to issue clear statements affirming their commitment to academic freedom and controversial debate. Universities should adopt clear policies supporting academic freedom and steps to deal with challenges to academic freedom in order to support higher order thinking across the campus. Academics should be encouraged to promote critical thinking and have the right to participate in how universities are run without the fear of reprisals from university leaders.

Maintaining staff motivation is a major challenge for university leaders. Research has shown that a positive school culture was associated with increased student motivation and achievement, improved teacher collaboration, and improved attitudes among teachers toward their jobs (Sashkin \& Sashkin, 1990; Sashkin \& Wahlberg,1993; Ogawa \& Bossert, 1995).

Teachers influence students' performance if they are motivated themselves. Teacher quality has a significant impact on student's academic performance (Mwamwenda and Mwamwenda, 1989; Lockheed and Verspoor, 1991). More importantly, teachers' quality is intertwined with teachers' perception of their work life (Perry, Chapman and Snyder, 1995). Teacher job satisfaction is often regarded as an important determinant on the educational outcomes such as students' achievement (Heller, Rex and Cline, 1992; Leslie, 1989). 
Raynor (1974) stressed that the higher the expected importance or value of present activities is in relation to future personal goals, the higher is the motivation of individuals and the better is their performance and learning. School management needs to pay particular attention to the way they deal with teachers. Treating teachers with respect, providing good working environment and developing teachers' skills and competencies will motivate teachers to perform better. Sirgy (1986) stressed that when the higher order needs such as esteem and self-actualization needs are met, teachers will move towards a higher level of development. The more motivated are the teachers, the greater commitment they will place in their work. When teachers see that their students are progressing and achieving their targets, they become motivated as their esteem needs have been met.

Change can take place at two levels: the organizational level and the individual level (Kotter, 1996; Lewin, 1952; Richardson \& Placier, 2001). Change at the organizational level addresses issues such as organizational development and organizational climate. Change at the individual level addresses issues such as motivation, human behavior and beliefs and the relationship of the impact of these beliefs on the organization (Richardson \& Placier, 2001). Change favours firms that move from static competition towards dynamic improvements and those which are able to create knowledge faster than their competitors (Porter, 1990).

Practitioner research is a popular tool to investigate educational practices with the aim of reconceptualise and transform such practices (Campbell \& Groundwater-Smith, 2010). Kemmis (2009) uses the term "practitioner research" and "action research" interchangeably. Practitioner research is often carried out by practitioners themselves, usually with a view to resolving a specific problem (Campbell \& McNamara, 2009). The practitioner research is different from traditional forms of research because the research is usually taken by the practitioners as part of their work.

\section{DISCUSSION ON PROPOSED DETAILED FRAMEWORK}

This paper proposes a detailed framework of university sustainability incorporating various elements affecting private universities (Fig 2). It builds on the core engine comprising Equity, Diversity, Democracy and Quality discussed in Fig. 1. Presented as a concentric ring model, the outer ring comprises Strategy, Culture, Structure, Stakeholders, Resources, and Systems (Figure 3).

\section{Implementing new strategies}

A private university must reorientate itself to ensure its competitiveness. The concept of competitiveness involves both static and dynamic components. It needs a new paradigm shift to sustain its competitiveness. It must be able to manage its resources and capabilities effectively. Sustainable competitive advantage depends on the core competencies that yield long term benefits to the university. When the external 
environment is turbulent and complex, the university has to respond to align with the environment in order to thrive.

The increase in the availability of knowledge online necessitates a fundamental shift in the role of a university. As content is readily available online, teaching methods need to change to focus on contextualisation and student experience. Universities are engines of innovation and sources of new knowledge and ideas. At the same time, university leaders have to demonstrate a large degree of entrepreneurship in the face of competition.

Figure 3 illustrates our proposed framework, consisting of five main components for strategic improvements:

1. Improved Culture

a. An improved culture would encompass more inclusiveness from various participants. Universities have to encourage and support changes in the way decisions are made. An organization's capacity for learning determines whether or not it will thrive or fail (Senge, 1990). Excellence is more likely sustained in organization that promotes continuous collaborative learning rather than in organizations where top-down management approach is the norm. University leaders have to create an atmosphere of change which is conducive to innovation and encourage participation of its employees. Deep and sustained change requires attention over extended period (DuFour, 1999) and may a number of years. Commitment of the university leaders is a must to bring about a sustainable environment for learning. Staff learning is reinforced when they share ideas in faculty meetings and other school activities. Cultures that recognize and support staff learning will bolster a professional learning community.

b. Barney (2002) proposed linking a company's competitive strategy to performance. The three essential building blocks of high performance business are: (1) market focus and position; (2) distinctive capabilities; and (3) performance anatomy. High performing businesses all excel at managing five common disciplines: leadership, people development, technology enablement, performance management, and innovation. These five disciplines form the backbone of performance anatomy. Performance anatomy relates to the observable and actionable side of culture which an organization can actively manage. Applying this performance anatomy concept to private universities, university leaders have to relook at their own leadership styles, the way they interact with employees and their support for innovation.

c. The other aspects of culture in the performance anatomy framework are hidden and they relate to unwritten rules and collective memories. They may be hindrance to any change efforts which the university leaders wish to take. The culture of the university has to adapt to the demands of 
the industry. An adaptive culture allows the fine-tuning of the formal structures, introduce new strategies, and change the leadership styles, yet still inspire the same commitment in its employees. The university's culture needs to be aligned with its strategies and changes in its business environment.

2. Improved Structure

a. Sustained change can only be accomplished with the commitment of the leader to improve teaching and learning (Schmoker, 2006). A strong professional learning community is oriented to change and its success or failure depends on the commitment, persistence and entrepreneurialism of its leaders. Structural improvement also include capacity enhancement such as motivation, skills, knowledge and support. Adequate capacity is needed if the institution is to carry out reculturing efforts effectively.

3. Improved access to Resources

a. Private universities need to have access to an enlarged base of funding sources. These could include private as well as public funding in the form of government grants for research activities. Besides looking for new funding resources, university leaders also have to be mindful of competition around them. They have to be receptive to shifting to new market segments or focusing to distant markets that are not focused by the competitors (Gaur, 2007).

b. The infrastructure of the university, including facilities, is critical in attracting new students to join the institution. Private universities compete aggressively in upgrading their facilities to differentiate themselves from their competitors.

c. The technological readiness of the university will enhance its productivity and increase its efficiency. Having good information and communication technologies (ICTs) such as campus-wide WIFI access will enhance the learning environment of students and staff. ICT will transform the way education is delivered and supported. New platforms such as online learning will enhance students' experience.

4. Improved Systems

a. The proper management of university finances is critical for ensuring trust in the administration. Indicators capturing the quality of the management of finances should be reviewed periodically to highlight transparency and adherence to accounting standards.

b. Universities should reduce excessive bureaucracy, red tape and overregulation for this will discourage employees from proposing news ideas and initiatives to management. 
c. Universities need to continue to nurture their employees and provide the necessary training and development for skills upgrading. Academics need to learn to develop new curricula which are relevant to the industry before they can impart the knowledge to their students. Changing the university structure or introducing new instructional methods are not enough to alter the core assumptions about teaching and learning. To make a real difference, universities need to reorientate their curricula. The promotion of a curricula culture will change the way teachers view curriculum and empower them as curriculum designers.

d. Learning communities in which teachers meet regularly to talk about their teaching and learning creates a structure of continuous improvement for learning and change (Hord, 1997). At the same time, teachers need to be trained on new pedagogical skills as they often lacked peer supervision in their work. There is a wide multitude of teaching styles as many teachers developed teaching strategies that are highly idiosyncratic.

e. Introducing new scholarships into private universities is one way to increase their distinctiveness from public universities. As most private universities are not research universities, their approach to research may also differ from public universities. Their structures may warrant different epistemologies that create a category of practitioner research which are often marginalized by traditional research universities. The important thing to note is not which form of research is more superior or lacking in intellectual rigour, but the value and practical implication of the research.

5. Improved relationships with Stakeholders

a. Companies are looking to collaborate with universities more closely in the areas of research and product development activities. As businesses cut back on their R\&D budge, they are increasingly more reliant on universities to develop new products. This relationship benefits universities in that students will be able to supplement classroom learning with real life commercial projects. The quality of a university's business network has a bearing on its competiveness and growth.

b. Private universities need to attract new talent into their workforce. They have to study new models as the needs and aspirations of academics have changed. World-class universities are characterised by a high concentration of excellence and talent. They embrace diversity rather than homogeneity in their talent pool. The increase in integration and coordination of diverse talents creates opportunities for pedagogical reorientating and new learning relationships.

c. Students need to know the various options available for them, including the multiple entry and exit points, the career prospects and the range of curricular activities. For example, they would like to know if the university has dual degree partnership arrangements with foreign universities. The 
university needs to foster diversity in its student population in order to promote cross-cultural and international awareness. Universities also need to embrace life-long learning in their curriculum as working adults may return to the university to upgrade their skills and increase their chances of finding work in the area of their training. (Strosnider 1998). At the same time, universities should not ignore students' non-academic outcomes such as students' involvement in student governance and their understanding of their empowerment and personal identity. The development of Soft Skills components in the Public Universities in Malaysia could be infused into the curriculum of private universities.

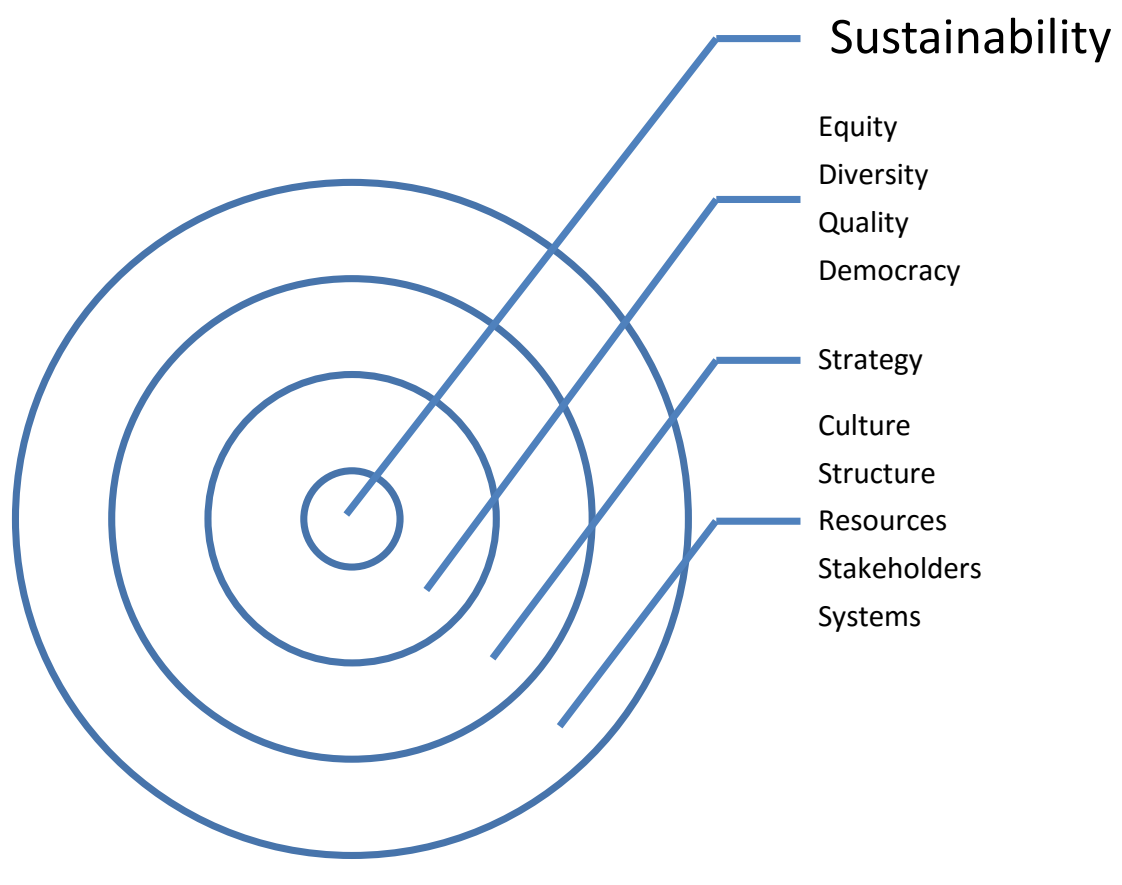

Figure 2: Detailed Framework of Sustainability in Private Universities 


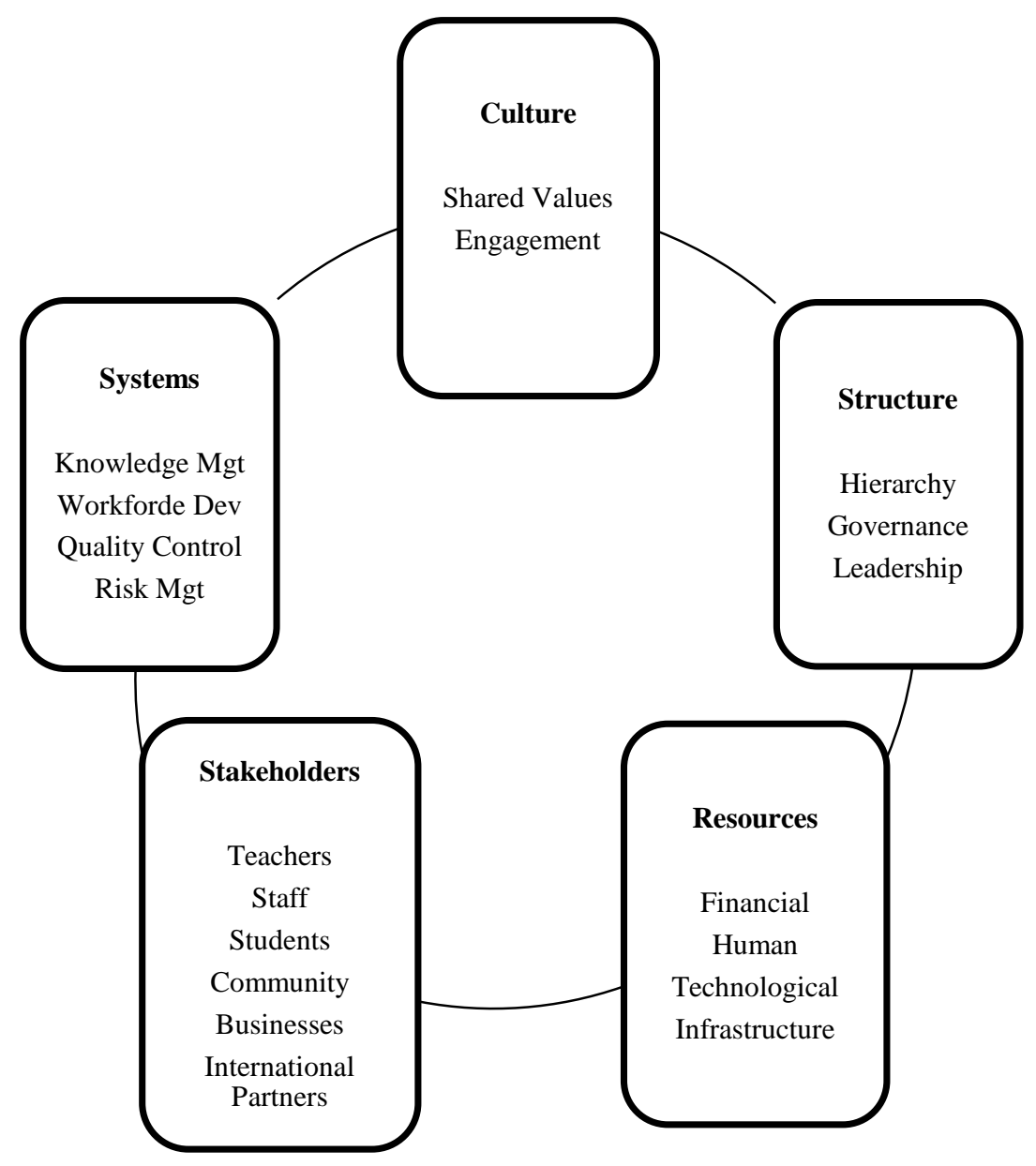

Figure 3: Detailed version of outer ring of framework

\section{CONCLUSION}

The five components in our proposed detailed framework for sustainability of private universities are not independent. They are highly intertwined and tend to reinforce each other. Universities are seen as the forefront of innovation where the goal is to contribute to the international competitiveness of the nation through educating their students and developing their human capital.

Universities need clear and strong cultures to foster professional learning. When universities have strong positive cultures, staff and student learning will thrive. Conversely, negative cultures can impair staff development. Teachers and staff professional development and quality curriculum are the keys to successful 
reorientation $\mathrm{g}$ of universities. University leaders must develop cooperative relationships with employees to build a strong learning community. With strong cultures of trust, openness and collaboration that support both students and staff learning, private universities will be able to sustain high performance and remain competitive in the long run.

The proposed framework in this paper has both theoretical and practical significance. It presents a detailed theoretical framework for private universities as learning institutions. University leaders should not lose focus on the four elements discussed in Fig. 1 that determine the universities sustainability. In addition, the proposed five components for strategic improvements elaborated in Fig. 2 will position them more competitively in the face of growing demands from students and staff. The practical contribution of this paper emphasises the necessary actions university leaders must take to ensure a sustainable institution.

\section{REFERENCES}

Barney, J.B. (2002). Gaining and sustaining competitive advantage. New Jersey: Prentice Hall

Barnett, R. (1990). The Idea of Higher Education. Buckingham, UK: Open University Press

Barnett, R. (2004). Learning for an unknown future. Higher Education Research \& Development, 23(3),247-260. http://dx.doi.org/10.1080/0729436042000235382

Boyd, W. (1992). The power of paradigms: Reconceptualizing policy and management. Educational Administration Quarterly, 29, 504-528. http://dx.doi.org/10.1177/0013161X92028004004

Campbell, A., \& Groundwater-Smith, S. (Eds.). (2010). Action research in education. Volume 1. Historical perspectives in action research in schools: from curriculum development to enhancing teacher professional learning. London: Sage.

http://dx.doi.org/10.4135/9781446260791

Campbell, A., \& McNamara, O. (2009). Mapping the field of practitioner research, inquiry and professional learning in educational contexts: a review. In A.Campbell \& S.Groundwater-Smith (Eds.), Connecting inquiry and professional learning in

education: international perspectives and practical solutions. (pp. 10-26). Abindgon, Oxon, U.K: Routledge

Coaldrake, P., \& Stedman, L. (1999). Academic work in the twenty-first century: Changing roles and policies. Occasional Papers Series (pp. 1-35). Canberra: Australian Department of Education, Training and Youth Affairs.

Doyle, L. H. (1998, April). The overlap of perspective in leadership, teaching,organization, and context.Paper presented at the American Education Research Asociation,San Diego, CA. 
DuFour, R. (1999). Help wanted: Principals who can lead professional communities. National Association of Secondary School Principals Bulletin, 83(604), pp.1217. http://dx.doi.org/10.1177/019263659908360403

DuFour, R., Eaker, R., DuFour, R., \& Karhanek, G. (2004). Whatever it takes: How professional learning communities respond when kids don't learn. Bloomington, IN: National Educational Service

DuFour, R. \& Eaker, R. (1998). Professional learning communities at work: Best practices for enhancing student achievement. Bloomington, Ind.: National Educational Service.

Fawcett, G., Brobeck, D. Andrews, S., \& Walker, L. (2001). Principals and beliefsdriven change. Phi Delta Kappan 82(5) pp. 405-410. http://dx.doi.org/10.1177/003172170108200512

Fessel, S. (2006). The impact of academic freedom policies on critical thinking instruction. Insight: A Collection of Faculty Scholarship, 1, 51-58.

Fullan, M. (1993). Change forces. Philadelphia: The Falmer Press.

Fullan, M. (2001). Leading in a culture of change. San Francisco: Jossey-Bass

Fulmer, R. M., Gibbs, P. A., \& Goldsmith, M. (2000). Developing leaders: How winning companies keep on winning. Sloan Management Review, Fall, 49-59.

Gaur, A.S. (2007). Essays on Strategic Adaptation and Firm Performance During Institutional Transaction. University of Singapore.

Geijsel, F.P., Sleegers, P.J.C., Stoel, R. and Krüger, M.L. (2007) The effect of

psychological, organizational and leadership factors on professional learning in

schools. Paper presented at the annual meeting of the American Educational

Research Association (AERA), Chicago, 9-13 April.

Hanna, D. E. (2003). Building a leadership vision: Eleven strategic challenges for higher education.Educause, July-August, 25-34.

Hargreaves, A. (1994). Changing teachers, changing times: Teachers work and culture in the postmodern age. London: Cassell

Hargreaves, A. (2003). Teaching in the knowledge society. New York: Teachers College Press

Heck, G., \& Hallinger. P. (1999). Next generation methods for the study of leadership and school improvement. In J. Murphy \& K. Seashore Louis (Eds), Handbook of research on educational administration (2nd ed). (pp. 141 - 162). San Francisco, CA: Jossey Bass Publishers

Heller.H., Rex,J.C., and Cline,M.P.(1992) Factors Related to Teachers Job Satisfaction and Dissatisfaction. ERS Spectrum, 10 (1), 20-24

Hord, S.M. (1997). Professional learning communities: Communities of continuous inquiry and improvement. Austin, TX: Southwest Educational Development Library 
Hord, S.M. (1998). Creating a professional learning community: Cottonwood Creek School. Washington, DC: Office of Educational Research and Improvement. (ERIC Document Reproduction No. ED424685).

Huffman, J. B., \& Hipp, K.K., Eds., (2003). Reculturing schools as professional learning communities. Lanham, MD: Scarecrow Publishing

Knight, P. T., \& Trowler, P. R. (2000). Department level cultures and the improvement of learning and teaching. Studies in Higher Education, 25,

69-83. http://dx.doi.org/10.1080/030750700116028

Huffman, J.B. \& Jacobson, A.L. (2003). Perceptions of professional learning communities. International Journal of Leadership in Education, 6(3), pp.239-250. http://dx.doi.org/10.1080/1360312022000017480

Kemmis, S. (2009). Action research as a practice-based practice. Educational Action Research, 17(3), 463-474. http://dx.doi.org/10.1080/09650790903093284

Kotter, J. (1996). Leading change. Boston, MA: Harvard Business School Press.

Lee, V. E., Smith, J. B., \& Croninger, R. G. (1995). Another look at high school

restructuring.Issues in Restructuring Schools. Madison, WI: Center on Organization and Restructuring Schools, Schools of Education, Univerisity of Wisconsin-Madison

Leithwood,K., Leonard, L., and \& Sharratt, L. (1998). Conditions fostering organizational learning in $\begin{array}{llll}\text { schools. Educational } & \text { Administration }\end{array}$ http://dx.doi.org/10.1177/0013161x98034002005

Leslie,K.(1989) Administrators Must Consider and Improve Teacher Satisfaction. NASSP Bulletin, 73,19-22. http://dx.doi.org/10.1177/019263658907351304

Lewin, K. (1952). Field theory in social science. London: Tavistock.

Lingard, B., Hayes, D., Mills, M., \& Christie, P. (2003). Leading learning. Philadephia: Open University Press

Lockheed, M. and Vespoor, A. (1991) Improving Primary Education in Developing Countries. Oxford: Oxford University press

Longden, B. (2006). An institutional response to changing student expectations and their impact on retention rates. Journal of Higher Education Policy and Management, 28(2), 173-187. http://dx.doi.org/10.1080/13600800600751044

McLaughlin, M. W. (1993). What matters most in teachers' workplace context? In J.W. Little and M.W. McLaughlin (Eds.), Teachers' work: Individuals, colleagues, and contexts (pp.79-103). New York: Teachers College Press

Meek, V. L., \& Wood, F. Q. (1997). Higher education government and management: An Australian study. Evaluations and Investigations Program, Higher Education Division, Department of 
Employment,Education, Training and Youth Affairs. January. Retrieved September 13, 2003, from http://www.detya.gov.au/archive/ highered/eippubs/eip9701/front.htm

Mwamwenda, T., and Mwmwenda, B. (1989) Teacher Characteristics and Pupils' Academic Achievemen in Botswana Primary Education, International Journal of Educational Development, 9(1). 31-42. http://dx.doi.org/10.1016/0738-0593(89)90006-0

Ogawa, R.., \& Bossert, S. (1995). Leadership as an organizational quality. Educational Administration Quarterly, 31, 224-243. http://dx.doi.org/10.1177/0013161X95031002004

Perry, P., Chapman,D., and Snyder, C. (1995). Quality of teacher worklife and classroom practices in Botswana, International Journal of Educational Development, 15(2). 115-125. http://dx.doi.org/10.1016/0738-0593(94)E0013-E

Porter, M: "The Competitive Advantage of Nations" London 1990. http://dx.doi.org/10.1007/978-1-34911336-1

Pratt, G., \& Poole, D. (1999). Globalisation and Australian universities, policies and impacts. International Journal of Public Sector Management, 12(6), 533-544. http://dx.doi.org/10.1108/09513559910301775

Ramsden, P. (1998). Managing the Effective University. Higher Education Research and Development,17(3), 347-370. http://dx.doi.org/10.1080/0729436980170307

Raynor, J.O. (1974) Relationships between achievement-related motives, future orientation, and academic performances, in: J.W.ATKINSON \& J.O.TAYNOR (Eds) Motivation and Achievement, pp.121-154 (Washington DC, Winston)

Richardson, V., \& Placier, P. (2001). Teacher change. Handbook of research on teaching (pp. 905947). Washington, DC: American Educational Research Association.

Sashkin, M., \& Sashkin, M. (1990). Leadership and culture building in schools: Quantitative and qualitative understandings. Paper presented at the annual meeting of the American Educational Research Association, Boston, MA.

Sashkin, M., \& Walberg, H. J. (1993). Educational leadership and school culture. Berkeley, CA: McCutchan Publishing Corporation.

Schmoker, M. (2006). Results now: How we can achieve unprecedented improvements in teaching and learning. Alexandria, VA: Association for Supervision and Curriculum Development

Senge, P.M.(1990). The fifth discipline: The art and practice of the learning organization. New York: Currency DoubleDay

Sirgy, M.J. (1986). "A Quality-of-Life Theory Derived from Maslow's Developmental Perspective." American Journal of Economics and Sociology, 45 (3), 328-342. http://dx.doi.org/10.1111/j.15367150.1986.tb02394.x

Sleegers, P. , Geijsel, F. and Dan Berg, R.V. (2002).Second International Handbook of Educational Leadership and Administration, pp. 75-102, K.Leithwood, P.Hallinger (eds), Dordrecht: Kluwer Academic Publisher. http://dx.doi.org/10.1007/978-94-010-0375-9_4 
Spillane, J. (2006) Distributed leadership. San Francisco, CA: Jossey Bass

Stein, M. (1998). High performance learning communities District 2: Report on Year One implementation of school learning communities. High performance training communities project. Washington, DC: Office of Educational Research and Improvement. (ERIC Document Reproduction No. ED429263).

Strosnider, K (1998). For-profit higher education sees booming enrolments and revenues. The Chronicle of Higher Education, p.A36

Snyder, H., Marginson, S., \& Lewis, T. (2007). "An alignment of the planets": Mapping the intersections between pedagogy, technology and management in Australian universities. Journal of Higher Education Policy and Management, 29(2), 1-16. http://dx.doi.org/10.1080/13600800701351769

Yu, S.O. (2009). Principal Leadership for Private Schools Improvement: The Singapore Perspective. The Journal of International Social Research, Vol 2/6, Winter 2009 